\title{
$12: 52103908-52111579$
}

National Cancer Institute

\section{Source}

National Cancer Institute. 12:52103908-52111579. NCI Thesaurus. Code C41687.

Physical location of AMHR2_Gene 